Teologia i Moralność, volumen 16(2021), numer 1(29)

doi: 10.14746/TIM.2021.29.1.12

ORCID: 0000-0002-3513-7264

\author{
MAREK SKIERKOWSKI \\ Uniwersytet Kardynała Stefana Wyszyńskiego w Warszawie \\ Wydział Teologiczny
}

\title{
„Oryginalna apologetyka” według papieża Franciszka
}

\section{Wstęp}

Jednym z impulsów papieża Franciszka danym środowiskom akademickim było zasugerowanie idei tzw. oryginalnej apologetyki. Chodzi tu - jak wyjaśnia ojciec święty w swojej programowej adhortacji apostolskiej Evangelii gaudium - „o spotkanie między wiarą, rozumem i nauką”, tyle że pod kątem „stworzenia takich postaw, aby Ewangelia była słuchana przez wszystkich" (Franciszek 2013, 132). W konstytucji apostolskiej Veritatis gaudium papież Franciszek dodał: „Powierzam przede wszystkim poszukiwaniom naukowym prowadzonym na uniwersytetach, wydziałach i w instytutach kościelnych zadanie rozwijania owej «oryginalnej apologetyki»»" (Franciszek 2017, 5). Naukowe kategorie myślenia przyjęte w głoszeniu Ewangelii mają się bowiem okazać „wodą przemienioną w wino” (Franciszek 2013, 132). Czym zatem dokładnie „na nowym etapie misji Kościoła” (Franciszek 2017, 1) może być ta, zasadniczo jedynie zasugerowana przez papieża Franciszka, oryginalna apologetyka? O jakie podejścia praktyczne tutaj chodzi, które umożliwiłyby wszystkim słuchanie Ewangelii?

\section{Nowy impuls dla teologii fundamentalnej}

Pierwszą refleksję, która rodzi się po lekturze wspomnianych tekstów papieskich, można sprowadzić do tezy, że ojciec święty Franciszek pragnie po prostu gruntownie zreformować jedną z kluczowych dyscyplin teologicznych, 
a mianowicie teologię fundamentalną, która wyrosła z nowożytnej apologetyki, a ta z kolei ze starożytnej apologii.

Greckie słowo apologia, oznaczające 'obronę', pojawia się po raz pierwszy w pismach Antyfonta (Antyfona) z Ramnus (480-411 przed Chr.), retora i sofisty (Fiedrowicz 2000, 18). Jeśli zaś chodzi o Stary Testament, to grecki rzeczownik apologia występuje tylko w Mdr 6,10: „Strzegący święcie świętości uświęceni zostaną i uczący ich znajdą obronę". Z kolei w Nowym Testamencie słowo apologia pojawia się osiem razy, przede wszystkim w 1 P 3,15: „Bądźcie zawsze gotowi do obrony (pros apologian) wobec każdego, kto domaga się od was uzasadnienia, tej nadziei, która w was jest" (zob. także Dz 22,1; 25,16; 1 Kor 9,3; 2 Kor 7,11; Flp 1,7.16; 2 Tm 4,16). Arystoteles (†322 przed Chr.) w Retoryce (I, 3, 1358b, 5) wyróżniał ze względu na adresatów trzy rodzaje wymowy: „doradczą (polityczną), sądową i popisową” (Arystoteles 1988, 76). Apologię przeciwstawiał kategorii (I, 3, 1358b, 10-25), czyli umieszczając ją w obrębie mowy sądowej; w sporze dwóch stron trzeba bowiem zająć jedną z tych pozycji (Arystoteles 1988, 76-77). Wzorem antycznej apologii pozostaje dzieło Platona ( $† 347$ przed Chr.) zatytułowane Obrona Sokratesa (Apologia Sokratous), w którym tytułowy bohater właśnie, zagrożony sądową karą śmierci, broni się przed zarzutami (24c), iż ,popełnia niesprawiedliwość przez to, że demoralizuje młodzież oraz nie uznaje bogów uznawanych przez państwo, lecz inne nowe duchy" (Platon 2007, 39). W okresie narodzin chrześcijaństwa apologie, pojmowane jako polemika judaizmu z hellenizmem, tworzyli żydowscy pisarze, posługujący się językiem greckim, mianowicie Filon Aleksandryjski (†45/50) i Józef Flawiusz (†ok. 100). W spuściźnie tego pierwszego znajdują się m.in. Hipotezy (Hipothetica), z kolei ten drugi napisał apologię Przeciw Apionowi (Fiedrowicz 2000, 30).

Wprawdzie żadne pismo Nowego Testamentu nie stanowi typowej apologii, jednak wymiar apologijny przenika głoszenie Ewangelii od samego początku. Święty Paweł pisał: „Gdy Żydzi żądają znaków, a Grecy szukają mądrości, my głosimy Chrystusa ukrzyżowanego, który jest zgorszeniem dla Żydów, a głupstwem dla pogan, dla tych zaś, którzy są powołani, tak spośród Żydów, jak i spośród Greków - Chrystusem, mocą Bożą i mądrością Bożą" (1 Kor 1,22-24). Euzebiusz z Cezarei (†ok. 339) w kontekście rządów cesarza Hadriana (117-138) wspomina w swojej Historii kościelnej $(4,3,1)$ : „Temu właśnie cesarzowi Kwadratus zadedykował i ofiarował pismo zawierające apologię naszej religii, jako że pewni niegodziwi ludzie usiłowali wówczas szkodzić naszym braciom. Jeszcze dzisiaj znajduje się to pismo w rękach bardzo wielu braci i ja również je posiadam. Stanowi ono dowód wybitnych zdolności umysłowych i apostolskiej prawowierności tego człowieka" (Euzebiusz z Cezarei 2013, 225).

Taki właśnie był początek formalnego redagowania chrześcijańskich apologii. Orygenes $(\dagger 253 / 254)$ w słynnej apologii Przeciw Celsusowi (Kata Kel- 
sou) przypomina, że wiara jest najpierw darem łaski: „Szczęśliwy, kto czytając rozprawę Celsusa, nie potrzebuje żadnej apologii, lecz bez wahania nim pogardzi. Tak właśnie postąpi każdy, kto wierzy w Chrystusa, a to dzięki Duchowi, który w nim mieszka" (Orygenes 1986, 36). Orygenes nie chce zatem „zaciemnić blasku mocy Jezusowej, która powinna być oczywista dla każdego" (Orygenes 1986, 34). Następnie zwraca on jednak uwagę na racjonalność wiary: „Człowiek wykształcony w naukach greckich, który zetknie się z naszą nauką, nie tylko może uznać ją za prawdziwą, lecz również stosując ją w praktyce może potwierdzić prawdziwość chrześcijaństwa przez podanie pewnych uzupełnień, aby nasze argumenty harmonizowały z greckim sposobem dowodzenia. Trzeba wszakże $\mathrm{w}$ tym miejscu podkreślić, że nauka nasza posiada swoje własne dowody, napełnione mocą Bożą bardziej niż argumenty wywodzące się z zasad dialektyki greckiej. Ten boski sposób dowodzenia Apostoł nazywa «ukazaniem Ducha i mocy» $(1$ Kor 2,4$)$. Ducha - przez proroctwa, które potrafią utwierdzić w wierze każdego czytelnika, zwłaszcza w wierze, która dotyczy Chrystusa; mocy - za pomocą cudów, których istnienia można dowieść różnymi sposobami, ale przede wszystkim na podstawie tego, iż ich ślady przetrwały do naszych czasów w ludziach, którzy żyją zgodnie z nakazami nauki” (Orygenes 1986, 37-38).

Średniowiecze poszło tym tropem, podkreślając, że ostatecznie wiara nie tylko jest racjonalna, ale wręcz dodatkowo poszerza ona możliwości rozumu. Święty Anzelm (†1109), uważany za ojca scholastyki, pisał w dziele Proslogion, mającym charakter modlitwy, następująco: „Nie porywam się, Panie, by zgłębić Ciebie, bo nawet w przybliżeniu nie mogę porównywać mego intelektu do Twej wielkości; pragnę tylko pojąć przynajmniej do pewnego stopnia Twą prawdę, którą serce moje kocha i w nią wierzy. Nie zamierzam bowiem pojąć, by wierzyć, ale wierzę, by zrozumieć. Gdyż wierzę też w to, że «jeśli nie uwierzę, nie będę mógł zrozumieć» (Iz 7,9)" (Anzelm z Canterbury 2007, 199). W takim duchu powstawały liczne traktaty średniowieczne, na czele z Summa contra gentiles św. Tomasza z Akwinu (†1274).

Apologetyka, a więc konkretna nauka o wypracowanym statusie metodologicznym, ukształtowała się w epoce nowożytnej, kiedy zaczęto coraz bardziej kwestionować naukowy status teologii, przypisując jej charakter mądrościowy. Krystalizująca się apologetyka wykazywała zatem prawdziwość (1) religii, (2) Chrystusa i (3) Kościoła. Od kiedy Leon Ollé-Laprune (†1898) opublikował La Certitude morale (1880), zaczęto mówić nie tyle o dowodach, ile raczej o pewności moralnej wierzącego, wykluczającej rozumne wątpienie. Jeśli chodzi o sam termin apologetyka, to należy wskazać, że upowszechnił się on dopiero w pierwszej połowie XIX wieku. Katolik Johann Sebastian von Drey $(† 1853)$ z Uniwersytetu w Tybindze włączył apologetykę w struktury akademickie (Kurze Einleitung in das Studium der Theologie, 1819), 
a protestant Karl Heinrich Sack (†1875) wydał Christliche Apologetik (1829), pierwsze dzieło noszące w tytule nazwę apologetyka (Zieliński 2008, całość).

Wraz z Soborem Watykańskim II (1962-1965), którego dokumenty stanowią „doktrynalne arcydzieło XX wieku” (O’Collins 1993, 2), okazało się, że apologetyka, która wyrosła z konkretnych zapotrzebowań historycznych, w nowym kontekście (religijno-kulturowym) jest już niewystarczająca; z tej racji świadomie nie wzmiankowano jej ani razu w tekstach Vaticanum II. Niebawem, za sprawą teologów, pozateologiczna apologetyka zaczęła się przekształcać w teologię fundamentalną, czyli naukę o innym profilu. Samo określenie teologia fundamentalna występowało już dawniej w dziełach m.in. Petera Annatusa (z 1700 roku) czy Vitusa Pichlera (z 1713 roku), a przede wszystkim Johanna Nepomuka Ehrlicha $(\dagger 1864)$ (Waldenfels 1993, 78).

Określenie teologia fundamentalna stało się techniczną nazwą dyscypliny będącej spadkobierczynią klasycznej apologetyki (Tanzella-Nitti 2015, 181-252). Na początku XXI wieku Salvador Pié-Ninot (ur. 1941), teolog hiszpański, wskazywał istnienie dwóch wielkich modeli teologii fundamentalnej, mianowicie rzymskiego i niemieckiego. Ten pierwszy - wywodzący się tradycji Papieskiego Uniwersytetu Gregoriańskiego w Rzymie - pojmuje teologię fundamentalną jako teologię wiarygodności objawienia, ten drugi zaś - wywodzący się głównie z tradycji Uniwersytetu w Tybindze - pojmuje teologię fundamentalną jako teologię fundamentów objawienia (Pié-Ninot 2006, 41-51). Jednakże w okresie posoborowym nieustannie dopominano się także o apologijny (apologetyczny) wymiar teologii fundamentalnej. W ostatnich latach pojawiło się nawet określenie now a a pologia, sugerujące, z jednej strony, renesans apologii, a z drugiej jej kolejną fazę, której specyfiką ma być nade wszystko dialog (Artemiuk 2016, 544). Ta nowa apologia nie oznacza jednak wyparcia teologii fundamentalnej, lecz odnowienie, jej większe nachylenie ku dialogowi.

Ten rys historyczny, nawet nieco podręcznikowy, służył tylko jednemu celowi, a mianowicie, by naświetlić tendencję dostrzeganą $\mathrm{w}$ teologii fundamentalnej od wieków. Papież Franciszek zdaje się udzielać poparcia takiemu właśnie rozwojowi teologii fundamentalnej, chociaż nie zajmuje się nią szczegółowo. Jego nacisk na spotkanie (dialog) między wiarą, rozumem i nauką (czyli naukami szczegółowymi) z pewnością nie jest więc nowy, ale brzmi jak wyrzut sumienia wobec współczesności. W dołączonych do konstytucji apostolskiej Zarządzeniach wykonawczych Kongregacji ds. Edukacji Katolickiej w obrębie obowiązkowych dyscyplin teologicznych w pierwszym cyklu studiów wymienia się, na drugim miejscu po naukach biblijnych, „teologię fundamentalną, uwzględniającą także zagadnienia dotyczące ekumenizmu, religii niechrześcijańskich i ateizmu, jak również innych nurtów współczesnej kultury" (Franciszek 2017, art. 55b). Jest tutaj dostrzegalna zasadnicza ciągłość z Zarzadzeniami poprzednimi (tymi do konstytucji Jana Pawła II Sapientia 
christiana z 1979 r.), aczkolwiek nowością pozostaje człon o ,innych nurtach współczesnej kultury". Mamy zatem do czynienia raczej ze wzmocnieniem teologii fundamentalnej, a nie jej przeformatowaniem w oryginalną apologetykę. Wyrażając się jeszcze inaczej, papieska koncepcja oryginalnej apologetyki nie dotyczy, wbrew przywołanej technicznej nazwie, tylko rozwojowych perspektyw teologii fundamentalnej.

\section{Nowy impuls dla nauk kościelnych}

Z tej racji, że papież Franciszek ,zadanie rozwijania owej oryginalnej apologetyki” powierzył ,poszukiwaniom naukowym prowadzonym na uniwersytetach, wydziałach i w instytutach kościelnych", należy uznać, że jego koncepcja ma charakter interdyscyplinarny, a nawet interwydziałowy i interuczelniany, przynajmniej i nade wszystko w obrębie nauk kościelnych, czyli instytucji, „które zostały kanonicznie erygowane lub zatwierdzone przez Stolicę Apostolską" (Franciszek 2017, art. 2 par. 1). Ojciec święty umieszcza aktualną potrzebę reformy nauk kościelnych, a szczególnie teologii, jeszcze wyraźniej, niż czyniono to dotychczas, w kontekście „misji ewangelizacyjnej Kościoła” (Franciszek 2017, 1). Już w swojej programowej adhortacji apostolskiej Evangelii gaudium ojciec święty prosił teologów, „by nie zadowalali się teologią uprawianą przy biurku" (Franciszek 2013, 133). Z tej racji wypowiadał się później o konieczności „duchowej atmosfery badań naukowych” (Franciszek 2017, 3) i przynaglał, by uprawiać teologię „na kolanach” (Franciszek 2017, 3). Wskazywał na niewyczerpany dynamizm pracy teologicznej: „Dobry teo$\log$ i filozof ma myśl otwartą, to znaczy niepełną, zawsze otwartą na Boże maius i na prawdy nieustannie się rozwijające" (Franciszek 2017, 3). Z kolei w adhortacji apostolskiej Gaudete et exsultate (o powołaniu do świętości w świecie współczesnym) papież Franciszek przestrzegał teologów przed tzw. gnostycyzmem, czyli przekonaniem, że oni „dzięki swoim wyjaśnieniom mogą uczynić doskonale zrozumiałą całą wiarę i całą Ewangelię. [...] Czym innym jest zdrowe i pokorne wykorzystywanie rozumu do refleksji nad nauczaniem teologicznym i moralnym Ewangelii; czym innym natomiast jest próba zredukowania nauczania Jezusa do zimnej i surowej logiki, która dąży do panowania nad wszystkim" (Franciszek 2018, 39). Pokora teologów bazuje na tym, że „Bóg nas nieskończenie przerasta, zawsze jest zaskoczeniem i nie my decydujemy o tym, w jakich okolicznościach historycznych można Go spotkać, bo nie od nas zależy czas i miejsce, i sposób spotkania. Ten, kto chce, aby wszystko było jasne i pewne, usiłuje zapanować nad transcendencją Boga" (Franciszek 2018, 41). W perspektywie naukowego dialogu niezwykle istotne jest przypomnienie papieża Franciszka, że ,prawdę, którą otrzymuje- 
my od Pana, możemy pojąć jedynie w sposób bardzo niedoskonały. Z jeszcze większą trudnością udaje się nam ją wyrazić. Dlatego nie możemy udawać, że nasz sposób rozumienia upoważnia nas do sprawowania ścisłego nadzoru nad życiem innych" (Franciszek 2018, 43). Dzisiejsze nauki kościelne nie mogą przeoczyć tego, że ,doktryna, lub lepiej: nasze jej rozumienie i wyrażanie, nie jest systemem zamkniętym, pozbawionym dynamiki zdolnej do rodzenia pytań, wątpliwości, dyskusji, a pytania naszego ludu, jego zmagania, marzenia, troski mają wartość hermeneutyczną, której nie możemy pomijać, jeśli chcemy poważnie potraktować zasadę wcielenia" (Franciszek 2018, 44).

Papież Franciszek wskazuje cztery ,podstawowe kryteria odnowienia i odrodzenia wkładu studiów kościelnych w Kościół wychodzący na misję” (Franciszek 2017, 4). Po pierwsze, teologia winna być duchowym, intelektualnym i egzystencjalnym wprowadzeniem w serce kerygmatu (Franciszek 2017, 4a). Po drugie, ma być uprawiana w dialogu, ale rozumianym nie tylko ,jako zwykłe podejście taktyczne, ale jako nieodłączny wymóg, by zyskać wspólnotowe doświadczenie radości prawdy" (Franciszek 2017, 4b). Po trzecie, teologia nie może tracić z oczu ,inter- i trans-dyscyplinarności realizowanej z mądrością i kreatywnością w świetle Objawienia" (Franciszek 2017, 4c). I po czwarte, jej skuteczność zależy od stworzenia ,sieci pomiędzy różnymi instytucjami” (Franciszek 2017, 4d). Ponadto, studium Biblii ma „być jakby duszą teologii” (Franciszek 2017, art. 70,1), refleksja nad wiarą winna dokonywać się „,w powiązaniu z osiągnięciami naukowymi bieżącej epoki” (Franciszek 2017, art. 71,1), aczkolwiek apologecie nie wolno ,zaakceptować systemów i metod, których nie da się pogodzić z wiarą chrześcijańską" (Franciszek 2017, art. 71,2).

W oficjalnych tłumaczeniach papieskiej programowej adhortacji apostolskiej oryginalna apologetyka zyskuje takie nazwy, jak np. a creative apologetics, un'apologetica originale bądź eine ursprüngliche Apologetik. Chodzi tu zatem przede wszystkim o wynikające z samego faktu stworzoności świata predyspozycje do wybronienia Ewangelii przed zarzutem, że jest ona nieuprawnioną ingerencją w ludzkie życie, jakby przesądem, ciemnością, obcym ciałem. Stąd właśnie ta apologetyka, czyli sztuka obrony, jest pierwotna (ursprüngliche), stwórcza (creative) czy oryginalna (originale), bo ufundowana na samym fakcie stworzenia świata przez Boga, wynikająca z tej pierwotnej (i dlatego oryginalnej) zależności świata od Stwórcy. Papież Franciszek wyraźnie naprowadza odbiorcę adhortacji Evangelii gaudium na to, że tu chodzi o uformowanie takich postaw, które warunkują przyjęcie (słuchanie) Ewangelii w świecie, który wyszedł z ręki Boga, nosi wszczepioną przez Niego otwartość na to, co transcendentne. „Studia kościelne - wyjaśnia ojciec święty - nie mogą ograniczać się do przekazywania wiedzy, umiejętności, doświadczenia mężczyznom i kobietom naszych czasów, pragnących rozwijać się w swojej świadomości chrześcijańskiej, ale muszą podjąć naglące zadanie wypracowa- 
nia narzędzi intelektualnych zdolnych, by zaoferować się jako paradygmaty działania i myśli, przydatne do głoszenia [Ewangelii] w świecie naznaczonym pluralizmem etyczno-religijnym" (Franciszek 2017, 5). Jakie zatem konkretnie postawy w tym względzie trzeba wypracować?

Z tej racji, że cała ludzka wiedza obejmuje ogólnie nauki szczegółowe, filozofię i teologię, można odpowiednio wskazać trzy postawy etyczno-moralne: (1) zdumienie wobec racjonalności świata i lęk wobec zobojętnienia świata; (2) odpowiedzialne stawianie pytań o głębszy sens rzeczywistości; (3) gotowość do zaangażowania się w owocną recepcję daru Bożego objawienia.

Przedstawiciele nauk szczegółowych (czyli po prostu rozum scjentystyczny) są przekonani, że dostępny świat ma charakter racjonalny i dlatego jest możliwy do naukowego badania; fascynacja naukami to inaczej podziw dla inteligibilności rzeczywistości. Jednocześnie świat ukazuje wobec ludzi pewien rodzaj zobojętnienia, wywołuje lęk, bo nie udziela człowiekowi ostatecznego sensu. Blaise Pascal (†1662) pisał w Myślach (n. 84): „Czymże jest człowiek w przyrodzie? Nicością wobec nieskończoności, wszystkim wobec nicości, pośrodkiem między niczym a wszystkim. Jest nieskończenie oddalony od rozumienia ostateczności; cel rzeczy i ich początki są dlań na zawsze ukryte w nieprzeniknionej tajemnicy; równie niezdolny jest dojrzeć nicości, z której go wyrwano, jak nieskończoności, w której go pogrążono" (Pascal 1999, 53).

Przyjmijmy za znaczącą grupą uczonych, że początek Wszechświata wyznacza Wielki Wybuch (Big Bang; pomysł E. Hubble’a, †1953), który nastąpił 13,7 mld lat temu. Nasz Układ Słoneczny (czyli Słońce i powiązane z nim grawitacyjnie ciała niebieskie, przede wszystkim planety, z Ziemią na czele) ukształtował się ok. 4,6 mld lat temu. Znajduje się on w obrębie Drogi Mlecznej, czyli jednej z setek miliardów galaktyk (układów gwiazd; w Drodze Mlecznej, czyli po prostu Galaktyce, jest ponad $100 \mathrm{mld}$ gwiazd). Mniej więcej miliard lat później, czyli 3,7 mld lat temu, pojawiło się życie (bakterie). Homo sapiens zaistniał w Afryce ok. 300 tysięcy lat temu; tuż przed nim był homo erectus (ok. 1,8 mln lat temu, człowiek wytwarzający narzędzia, panujący już więc w pewien sposób nad środowiskiem), a jeszcze wcześniej homo habilis; ok. 2 mln lat temu, człowiek zręczny, posługujący się narzędziami (zob. Edwards 2013). Jakie jednak jest źródło i cel takiego biegu dziejów?

Warto jeszcze tylko nadmienić, że w Polsce Michał Heller, prezbiter tarnowski, wypracowuje od lat koncepcję teologii nauki. O ile bowiem, jego zdaniem, filozofia nauki rozwija się w świecie intensywnie przynajmniej od pół wieku, o tyle teologia nauki jakby za tym rozwojem nie nadążała, pozostając „ciągle jeszcze dyscypliną rozproszoną” (Heller 2019, 83). Chodzi w niej po prostu o „teologiczną refleksję nad nauką” (Heller 2019, 6), w tym szczególnie nad naukami przyrodniczymi (por. Heller 2019, 39). Dyscyplinami pokrewnymi wobec teologii nauki są przede wszystkim teologia naturalna 
i teologia filozoficzna. Ta pierwsza ma według M. Hellera „ukazywać, że perspektywa teologiczna spójnie integruje to, co odsłania nauka, z innymi obszarami aktywności człowieka, takimi jak kultura, świat wartości, a nawet ekonomia i polityka" (Heller 2019, 107-108). Dawniej pojmowano ją jako namysł nad Księgą Przyrody, czyli stworzeniem, bo teologia właściwa zajmowała się Księgą Objawienia (koncepcja „dwóch Ksiąg”; Heller 2019, 40). Teologia filozoficzna z kolei „stosuje metody filozoficzne do badań teologicznych” (Heller 2019, 113), czyli jej przedmiotem ,są rozmaite zagadnienia teologiczne, do których można stosować metody filozoficzne" (Heller 2019, 113).

Z kolei filozofia, która oznacza dosłownie 'umiłowanie mądrości' (greckie filein - 'miłować'; sofia - 'mądrość'), jest naturalnym owocem ludzkiej fascynacji światem i lęku przed nim. Na przełomie VII i VI wieku przed Chr. Tales z Miletu postawił pytanie dotyczące całej rzeczywistości, mianowicie o przyczynę i cel wszystkiego. Poszukiwał on faktycznie - jak zaczęto później mówić - arche bytu, które miało być samozrozumiałe, a przez odwołanie się do niego wszystko inne miałoby się stać w jakiejś mierze zrozumiałe; w okresie nowożytności zaczęto bardziej posługiwać się łacińskim słowem absolutus (absolut nie ma już dalszych odniesień, jest bezwarunkowy, ostateczny). Z biegiem czasu filozofa sformułowała precyzyjniej pytania, które najbardziej nurtują człowieka; najważniejsze spośród nich Martin Heidegger (†1976) wyartykułował następująco: „Dlaczego w ogóle jest raczej byt niźli nic?” (Heidegger 1995, 24). Specyfiką zatem filozofa - jak twierdził Paul Tillich (†1965) - jest ,postawa radykalnego pytania”, „,czyste rozpoczynanie - rozpoczynanie bez posiadania, bez czegokolwiek, co byłoby z góry dane" (Tillich 1994, 29). Nieco paradoksalnie, ale jednocześnie bardzo ekspresyjnie, określił filozofię Friedrich W.J. Schelling (†1854): „nauka, która zaczyna od samego początku” (Schelling 2002, 19).

Niemożliwe jest, ale i nie ma potrzeby, by w tym miejscu dokonać syntezy tylu wieków filozofii, jej wszystkich dziedzin i rozlicznych nurtów. Wydaje się jednak, że najbardziej oczywisty owoc filozofii uchwycił Sobór Watykański I w Konstytucji dogmatycznej o wierze katolickiej Dei Filius (1870), stwierdzając, że z rzeczy stworzonych można naturalnym światłem rozumu ludzkiego poznać „początek i cel wszystkich rzeczy”. Teologia określa ten ,początek i cel wszystkich rzeczy" słowem Bóg. W poznaniu filozoficznym jest On tajemnicą, która „milczy i wygląda jak nicość” (Rahner 1987, 45). Według Karla Rahnera ( $\dagger 1984)$, jest to ostatnie słowo człowieka poprzedzające całkowite milczenie” (Rahner 1987, 44); bez tego słowa człowiek „utknąłby w świecie i w sobie" (Rahner 1987, 45). Filozofia stwarza warunki dla uzasadnionej nadziei, że Bóg może łaskawie objawić się ludzkości.

I właśnie teologia - jak pisał niegdyś Joseph Ratzinger - „wypełnia końcowe zadanie myśli filozoficznej” (Ratzinger 2009, 427). Sam termin „teologia” 
(w grece theos - 'Bóg', logos - 'słowo', 'nauka') ma pochodzenie przedchrześcijańskie i pozabiblijne. Po raz pierwszy pojawił się on w piśmie Platona Politeia (Państwo; II, XVIII, 379a). W Nowym Testamencie występuje termin theodidaktoi ('nauczeni przez Boga'; por. 1 Tes 4,9). Nieobecne w Biblii słowo te ologia, obciążone znaczeniem pogańskim, z trudem więc zyskiwało sobie prawo obywatelstwa w świecie chrześcijańskim. Od końca średniowiecza stało się ono już terminem technicznym określającym ludzki wysiłek zmierzający do zrozumienia Bożego objawienia przyjmowanego w wierze Kościoła. Najsłynniejsza definicja teologii brzmi: fides quaerens intellectum ('wiara poszukująca zrozumienia'). Nietrudno zatem zauważyć, że teologia żyje z paradoksu związku wiary i wiedzy. Statusu naukowego teologii nie odbiera to, że bazuje ona na darze objawienia Bożego, byleby tylko spełniała specyficzne wymogi rozumu poprzez refleksję spekulatywną. W tej perspektywie papież Franciszek nakreśla następujące cele wydziałom teologii: „Zadaniem wydziału teologii jest pogłębienie i systematyczne wyjaśnianie, zgodnie z właściwą jej metodą, nauki katolickiej - zaczerpniętej z największą troską z Bożego Objawienia; ponadto poszukuje rzetelnych rozwiązań ludzkich problemów w świetle tegoż Objawienia" (Franciszek 2017, art. 69).

Nietrudno zatem zauważyć, że idea oryginalnej apologetyki jest niejako hasłowym ujęciem nowego paradygmatu nauk kościelnych. „Dzisiaj - kontynuuje Ojciec Ś Swięty Franciszek - jesteśmy świadkami nie tylko czasu przemian, ale czasu prawdziwej i w pełnym tego słowa znaczeniu zmiany epoki. [...] Konieczne jest stworzenie przywództwa, które wskazałoby drogi. To ogromne zadanie, którego już nie można odkładać na później, wymaga na poziomie kulturowym formacji akademickiej i badań naukowych wielkodusznego i wspólnego zaangażowania ku radykalnej zmianie paradygmatu, a wręcz - śmiem powiedzieć - śmiałej rewolucji kulturowej. W tym trudzie globalna sieć uniwersytetów i fakultetów kościelnych jest powołana do wnoszenia decydującego wkładu zaczynu, soli i światła Ewangelii Jezusa Chrystusa i żywej Tradycji Kościoła, nieustannie otwartej na nowe scenariusze i nowe propozycje" (Franciszek 2017, 3). Nietrudno usłyszeć w tym tekście wołanie papieża Franciszka, by tak właśnie odnowione dyscypliny kościelne, a nie tylko sama teologia, objęły niejako duchowe przywództwo w świecie akademickim.

\section{Wniosek końcowy}

Gdy papież Franciszek wzmiankuje oryginalną apologetykę, nie proponuje zatem stworzenia nowej dyscypliny naukowej. Jego zasugerowana, ale nierozwinięta, idea oryginalnej apologetyki stanowi sztandar aktualnej odnowy nauk kościelnych w kontekście nowej ewangelizacji. Z jednej 
strony ojcu świętemu chodzi o bardziej praktyczne nachylenie samej teologii fundamentalnej (spadkobierczyni klasycznej apologetyki), ale jeszcze bardziej o spójną syntezę pomiędzy naukami szczegółowymi, filozofią i teologią w ogóle. Oznacza to wypracowywanie w profesorach i studentach uczelni czy wydziałów kościelnych, jak również we wszystkich korzystających z nauk kościelnych, a szczególnie $\mathrm{z}$ teologii, owych trzech zasadniczych postaw etyczno-moralnych (powinności) wobec rzeczywistości: (1) zachwytu nad racjonalnością świata i lęku wobec jego pewnego zobojętnienia w wymiarze czysto zewnętrznym, rzeczowym, powierzchownym, (2) otwierania się na nieuwarunkowaną tajemnicę bytu, jego pozazmysłową głębię oraz (3) gotowości do czerpania z obfitości Bożego objawienia przyjmowanego w żywej wierze. Wtedy właśnie proklamowana Ewangelia stanie się po prostu oczekiwanym spełnieniem ludzkiej istoty; Dobra Nowina odzyska w ten sposób swój pierwotny, oryginalny smak, będzie ona, używając metafory papieża Franciszka, ową wodą przemienioną w wino. Idea oryginalnej a pologetyki to ostatecznie imperatyw moralny skierowany do uczonych, by zachowali nienaruszone (wybronione) pierwszeństwo Boga w świecie.

\section{„A CREATIVE APOLOGETICS” ACCORDING TO POPE FRANCIS}

\section{SUMMARY}

The paper was inspired by the teaching of Pope Francis who wrote in the Apostolic Exhortation Evangelii Gaudium (2013) as follows: „Proclaiming the Gospel message to different cultures also involves proclaiming it to professional, scientific and academic circles. This means an encounter between faith, reason and the sciences with a view to developing new approaches and arguments on the issue of credibility, a creative apologetics which would encourage greater openness to the Gospel on the part of all. When certain categories of reason and the sciences are taken up into the proclamation of the message, these categories then become tools of evangelization; water is changed into wine” (n. 132). The article develops a notion ,a creative apologetics" as credible and ethical interaction between faith, reason and the sciences. The sciences teach us that the world is rational, although they remain simultaneously on the level of ordinary human usefulness only. The philosophical reason in turn leads us to a new horizon which opens itself beyond the reality of our five senses. Theology, finally, lets us accept and understand God`s revelation in Jesus Christ.

Keywords: theology, Francis, creative apologetics, credibility

Słowa kluczowe: teologia, Franciszek, oryginalna apologetyka, wiarygodność 


\section{BIBLIOGRAFIA}

Anzelm z Canterbury, św. 2007. Monologion. Proslogion, tłum. Leszek Kuczyński. Kęty: Marek Derewiecki.

Arystoteles. 1988. Retoryka. Poetyka, tłum. Henryk Podbielski. Warszawa: PWN.

Artemiuk, Przemysław. 2016. Renesans apologii, Płock: Płocki Instytut Wydawniczy.

Edwards, Denis. 2013. Jak działa Bóg?, tłum. Marek Chojnacki. Kraków: WAM.

Euzebiusz z Cezarei. 2013. Historia kościelna, tłum. Agnieszka Caba na podstawie przekładu Arkadiusza Lisieckiego, Kraków: WAM.

Fiedrowicz, Michael. 2000. Apologie im frühen Christentum. Die Kontroverse um den christlichen Wahrheitsanspruch in den ersten Jahrhunderten. Paderborn i in.: Ferdinand Schöningh.

Franciszek. 2013. Adhortacja apostolska «Evangelii gaudium» o głoszeniu Ewangelii we współczesnym świecie. Watykan. Dostęp: 01.05.2021. https://www.vatican.va/content/francesco/pl/apost_ exhortations/documents/papa-francesco_esortazione-ap_20131124_evangelii-gaudium.html.

Franciszek. 2017. Konstytucja apostolska «Veritatis gaudium»o uniwersytetach $i$ wydziałach kościelnych. Watykan. Dostęp: 01.05.2021. https:/www.vatican.va/content/francesco/pl/apost_ constitutions/documents/papa-francesco_costituzione-ap_20171208_veritatis-gaudium.html.

Franciszek. 2018. Adhortacja apostolska «Gaudete et exsultate» o powołaniu do świętości w świecie wspótczesnym, Watykan. Dostęp: 01.05.2021. https://www.vatican.va/content/francesco/pl/apost_ exhortations/documents/papa-francesco_esortazione-ap_20180319_gaudete-et-exsultate.html.

Heidegger, Martin. 1995. Znaki drogi, tłum. zbiorowe. Warszawa: Biblioteka Aletheia.

Heller, Michał. 2019. Nauka i teologia - niekoniecznie tylko na jednej planecie. Kraków: Copernicus Center Press.

Orygenes. 1986. Przeciw Celsusowi, thum. Stanisław Kalinkowski. Warszawa: Wydawnictwo ATK.

Pascal, Blaise. 1999. Myśli, tłum. Tadeusz Boy-Żeleński, w układzie J. Chevaliera. Warszawa: Instytut Wydawniczy PAX.

Pié-Ninot, Salvador. 2006. La teología fundamental. „Dar razón de la esperanza” (1 Pe 3,15). Salamanca: Secretariado Trinitario.

Platon. 2007. Obrona Sokratesa, thum. Ryszard Legutko. Kraków: OMP.

Rahner, Karl. 1987. Podstawowy wykład wiary. Wprowadzenie do pojęcia chrześcijaństwa, tłum. Tadeusz Mieszkowski. Warszawa: Instytut Wydawniczy.

Ratzinger, Joseph. 2009. Formalne zasady chrześcijaństwa. Szkice do teologii fundamentalnej, thum. Wiesław Szymona. Poznań: W drodze.

Schelling, Friedrich W.J. 2002. Filozofia objawienia. Ujęcie pierwotne, t. I, thum. Krystyna Krzemieniowa, Piotr Dehnel. Warszawa: Wydawnictwo Naukowe PWN.

Tanzella-Nitti, Giueseppe. 2015. Teologia della credibilità in contesto scientifico, t. 1: La teologia fondamentale e la sua dimensione di Apologia. Roma: Città Nuova.

Tillich, Paul. 1994. Pytanie o Nieuwarunkowane. Pisma z filozofii religii, thum. Juliusz Zychowicz. Kraków: Znak.

Zieliński, Sławomir. 2008. Podmiotowy charakter apologetyki francuskiej przełomu XIX i XX stulecia. Częstochowa: Kemot Drukarnia na Warcie.

Marek Skierkowski - ksiądz diecezji łomżyńskiej, profesor doktor habilitowany nauk teologicznych (od 2015), specjalizujący się w teologii fundamentalnej. Studiował w Akademii Teologii Katolickiej w Warszawie (1994-1999). Od 1999 roku zatrudniony na Wydziale Teologicznym Uniwersytetu Kardynała Stefana Wyszyńskiego w Warszawie (aktualnie w Katedrze Teologii Fundamentalnej i Prakseologii Apologijnej). W międzyczasie prowadził także wykłady w insty- 
tucjach kościelnych Łomży, Ełku, Suwałk, Grodna i Wilna. Jego zasadniczy obszar zainteresowań to Jezus historyczny, szczególnie nurt Third Quest, a także historia teologii i apologii. Opublikował m.in. Jezus historii i wiary. Chrystologia fundamentalna Geralda O'Collinsa (2002); „A swoi Go nie przyjęli” (J 1,11). Teologicznofundamentalna interpretacja Third Quest (2006); Powotanie i warsztat teologa. Wprowadzenie do teologii (2012); Uczłowieczony Bóg. Chrystologia fundamentalna (2013). 